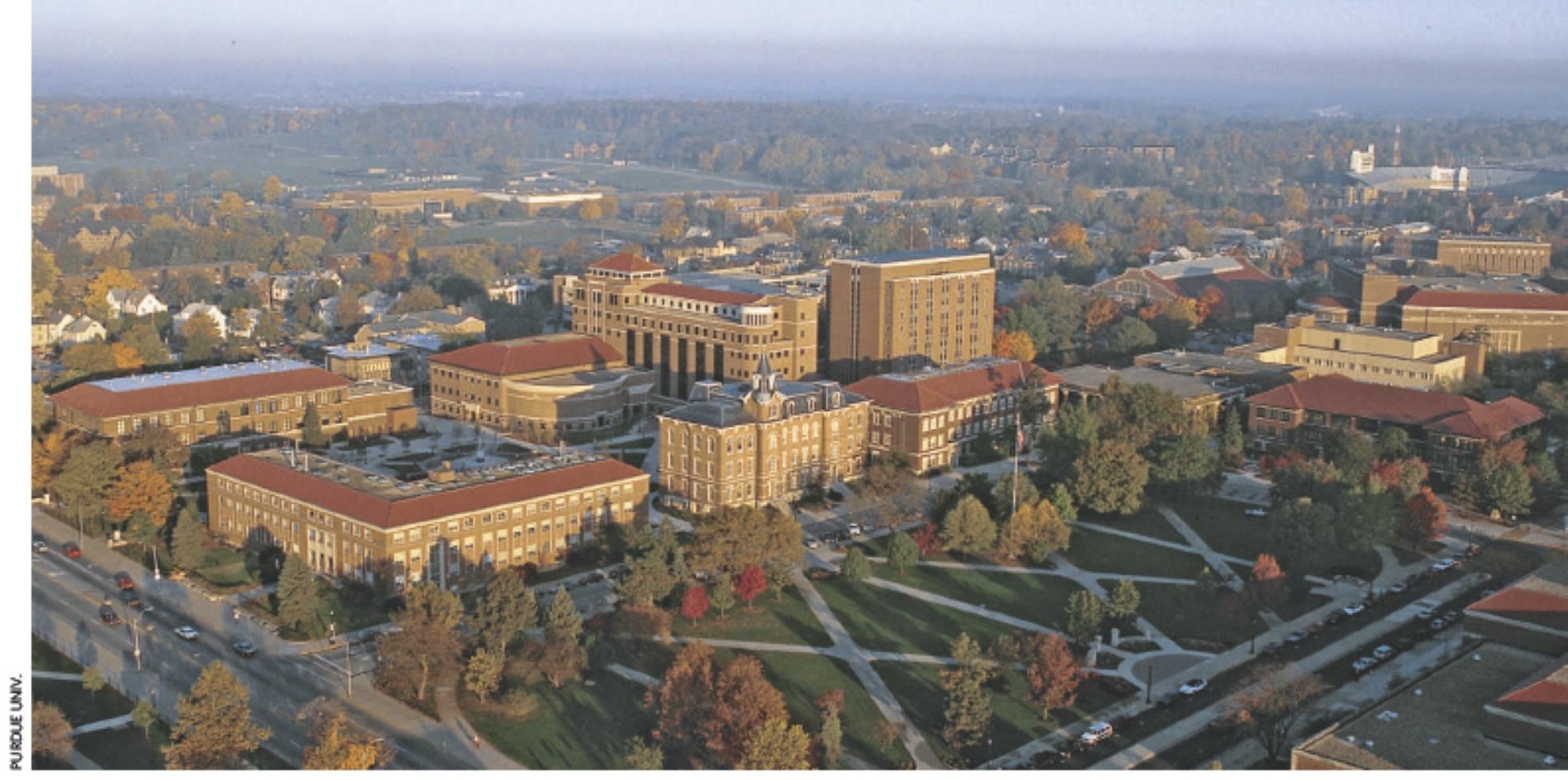

\title{
Misconduct? It's all academic...
}

\section{The legal quagmire, strain and bad press of misconduct investigations leave many universities tempted to ignore misconduct allegations. But getting an investigation right can reduce the pain and boost an institution's reputation, says Geoff Brumfiel.}

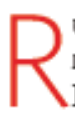
umours were flying at Purdue University nuclear engineering school in West Lafayette, Indiana, late in 2005. A recently hired physicist, Rusi Taleyarkhan, claimed to be pioneering a new form of energy called bubble fusion. But researchers both in and outside Purdue had concerns. Questions ranged from whether the neutron radiation in his experiment was from fusion or another source, to whether a supposedly independent confirmation of his findings was ghostwritten by Taleyarkhan.

Lefteri Tsoukalas, then dean of the school, asked the administration to launch a misconduct investigation. What happened next Tsoukalas describes as "a real eye-opener". For a month, he says, the administration ignored his request. An inquiry began only in March 2006, after Nature reported his and others' concerns (see Nature 440, 132; 2006).

But even since then, Tsoukalas says, little has been done. In October 2006, he resigned (see Nature 444, 664; 2006), saying that he has "little faith that Purdue is capable of running a research integrityinvestigation". Taleyarkhan has denied all wrong-doing. Purdue dedines to comment.

The situation benefits no one, but is far from unique. Research ethicists and university misconduct officers say that academia's handling of scientific misconduct is often capricious and incomplete. Reasons are complex, but essentially come down to three issues: investigations are laborious; they require legal and scientific expertise that administrators often don't have; and universities may fear that a guilty verdict will stain their reputation.

Countries vary in their approaches, but a look at US universities highlights the problem. Many ethicists told Nature the system is riddled with inconsistencies. 'I wouldn't even go so far as to glorify the current arrangement as 'a system," says Arthur Caplan, a bioethicist at the University of Pennsylvania in Philadelphia.

\section{Little guidance}

Most US misconduct proceedings follow a similar arc. If an accusation is received, administrators launch a preliminary inquiry. If that finds enough evidence, the university can open a full investigation. But beyond that, there's little guidance. Organizations such as the National Academies and the government's Office of Research Integrity (ORI) provide guidelines on research conduct, but no single document lays out investigative procedures.

Trouble can begin before the inquiry, says Kristina Gunsalus, a lawyer at the University of Illinois at Urbana-Champaign, who has led many proceedings. It's often unclear where whistleblowers should take their concerns, so young students end up discussing them with senior colleagues. The gossip that follows can damage the accused and prejudice an inquiry. Whistleblowers can also be the target of reprisals. Young people in particular are rarely protected, according to Barbara Redman, dean of nursing at Wayne State University in Detroit, Michigan, who has studied the issue. "Policies are incomplete," she says. Many lose their jobs, regardless of the outcome of their allegations.

Once an investigation starts, it can quickly enter legal limbo. Misconduct is not a legal charge, so in one sense it comes down to university policy. But if anyone is defamed, the university can find itself with a libel case. So it has a strong incentive to be secretive.

Then there's the pressure on investigators, generally scientists at the university, who are expected to serve as judge and jury to their colleagues. This can be awkward. Proceedings are often protracted and complex, with months of hearing testimony and evidence. "Every committee I have ever worked with comes back with these enormous circles under their eyes," says Gunsalus. "I cannot overstate the costs of these procedures for the people involved."

In part because the panels are made up of working scientists, they can deliver unexpected results. One recent example is the University of Pittsburgh's investigation into Gerald Schatten, an obstetrics professor. Schatten collaborated heavily with disgraced stem-cell scientist Woo Suk Hwang of Seoul National University (SNU) in South Korea. The SNU's investigation found that Hwang had faked many of his acclaimed cloning results, and a panel at Pittsburgh was 
charged with determining whether Schatten was also guilty of misconduct.

The panel concluded he was not, but found him guilty of 'research misbehaviour' - a term undefined by university policy and not included in the original charges. "What does it mean and what are the consequences?" asks Gunsalus. "I wish they had done better."

It's not surprising that the legal quagmire, strain and bad press leave many universities tempted to ignore allegations. "Universities have an incentive not to pursue them," says Redman. "They don't want to disgrace their faculty, adds Caplan. "It hurts morale."

Similar problems exist elsewhere. In Britain, for example, major funding bodies such as the research councils and the Wellcome Trust only award grants to universities that have established systems for dealing with misconduct allegations. But there is no body with the power to oversee investigations when they occur.

What can be done? One possible solution is to take investigations out of universities' hands and pass them to an independent body. But this can be controversial, as scientists don't take kindly to investigation by outsiders. The ORI briefly tried to take the lead in the late 1980 s, but its heavy-handedness and lack of scientific expertise led to a backlash, according to Caplan: "The ORI blundered around like a brontosaurus in the research misconduct park."

Today, the ORI takes a lower-key role, providing guidelines and reviewing cases involving federal funds. Despite the failings of universities, most people now agree that in a country such as the United States, with a highly privatized university system, it's best to handle misconduct investigations on campus. "There are no better alternatives," says Gunsalus.
Scandinavian countries seem to fare better with independent supervision. In Denmark, whistleblowers can turn to a government body called the Danish Committees on Scientific Dishonesty (DCSD) if they think university boards have not investigated a claim properly. Finland and Norway have similar committees. Although some of the DCSD's decisions have been controversial, such as when it criticized climate sceptic Bjørn Lomborg for cherrypicking data in his 2001 book The Skeptical Environmentalist, it is generally seen as a model for small countries in which it is hard to find independent investigators at the local level.

However, even DCSD member Vagn Lundsgaard Hansen, a mathematician at the Technical University of Denmark in Lyngby, believes claims should be dealt with by the university concerned where possible.

One way to help universities is to establish common systems and guidelines - although persuading them to comply isn't easy. After Germany's main funding agency, the DFG, asked universities to adopt guidelines in the late 1990s, it finally had to threaten to withdraw eligibility for funding if they didn't comply by mid-2002. The guidelines include establishment of university and DFG ombudsmen to whom whistleblowers can turn with concerns about a lab, and a committee that adjudicates on cases forwarded to it by the ombudsmen.

The universities reluctantly adopted the guidelines. But the ombudsmen expressed concern last October that universities are still not taking referred cases seriously. They complained that university presidents and rectors

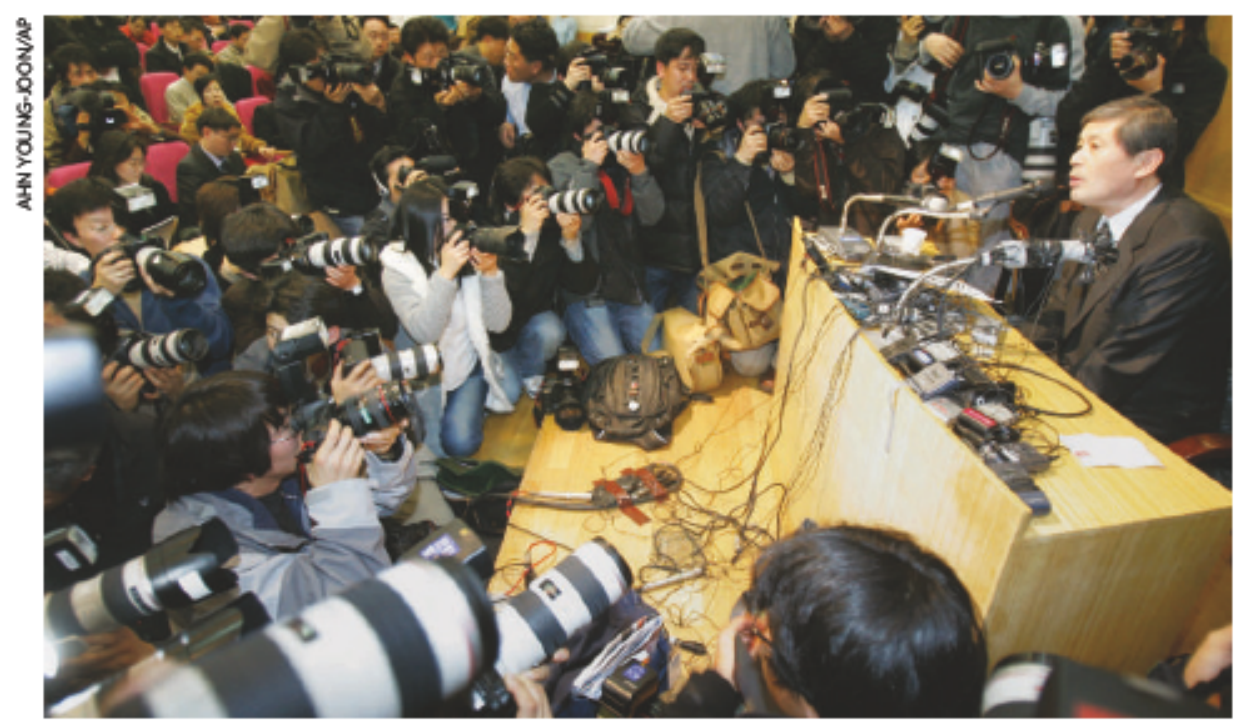

Different approaches: Purdue University (topleft) is accused of dragging its feet, whereas the investigation of Woo Suk Hwang (above) in South Korea started promptly and took just four weeks.

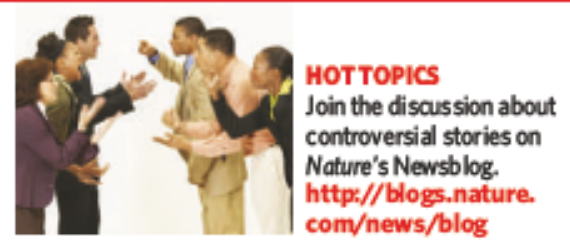

play down cases, particularly concerns brought by young scientists against more senior colleagues. And when investigations do get started they drag on. The ombudsmen pledged to increase pressure on universities to improve - perhaps by requiring DFG grant application forms to refer to the university's guidelines, thus forcing department heads, who co-sign applications, to explicitly endorse them.

The key may be to convince universities that getting it right can bolster their reputation. The Massachusetts Institute of Technology (MIT) in Cambridge was widely praised for its investigation of immunologist Luk van Parijs, begun in August 2004. MIT moved fast to determine if an investigation was needed, handled complaints confidentially, found him guilty of fabricating results and fired him in October 2005.

Some Asian universities - once notorious for brushing misconduct claims under the carpet - are now showing the world how to conduct fast, fair and transparent investigations.

\section{Quick justice}

Last August members of a lab run by veteran biologist Akio Sugino at Osaka University claimed he had faked data in two papers. Two days later the biosciences school to which Sugino belonged formed an investigation committee, and released its conclusion that Sugino had fabricated data the next month. The 40 -page report was published on the school's website and in December Sugino was dismissed.

That month the University of Tokyo concluded its investigation, begun in April 2005, into RNA researcher Kazunari Taira and his assistant. It reported that they were unable to provide notebooks to back up their results or to reproduce their experiments and, although it stopped short of finding fraud, fired both.

And in South Korea, the SNU completed its investigation into Hwang in four weeks, publishing its 50-page report on 10 January 2006.

Hisato Kondoh, dean of Osaka University's biosciences school, describes the secret of a successful investigation. "It's important to judge things based on facts, and make the results open as soon as possible, while protecting the rights of people who both reported allegations and are suspected," he says. "If the investigation takes time, everybody gets exhausted. Settling the case at the earliest possible opportunity and bringing the situation back to normal benefits all of us."

With additional reporting by Alison Abbott, David Cyranoski, Ichiko Fuyuno, Jim Giles and Lucy Odling-Smee.

See Editorial, page 229. 